\title{
Specifics of Developing Professional Thinking in Law Students
}

\section{Aspectos específicos del desarrollo del pensamiento profesional en estudiantes de derecho}

Marina Georgiyevna Sergeeva

Research Institute of the Federal Penitentiary Service of Russia, Moscow, Russia https://orcid.org/0000-0001-8365-6088

\section{Ivan Sergeyevich Samokhin}

Peoples' Friendship University of Russia (RUDN University), Moscow, Russia https://orcid.org/0000-0002-2356-5798

\section{Pavel Rustamovich Bazarov}

Research Institute of the Federal Penitentiary Service of Russia, Moscow, Russia https://orcid.org/0000-0002-6295-3646

\section{Matvey Nikolaevich Pyankov}

Research Institute of the Federal Penitentiary Service of Russia, Moscow, Russia https://orcid.org/0000-0003-4087-6050

*Correspondencia

Email: sergeeva198262@mail.ru 


\section{Summary}

The article examines the essence, role and significance of professional thinking within lawyers' professional development, making a special emphasis on the specifics of evolving law students' professional thinking. The research purpose is a theoretical and empirical study of the developmental specifics of law students' professional thinking. Besides, there is a focus on the structure and features of lawyers' professional thinking as a special professionally important quality. The authors conduct a comprehensive analysis of the developmental specifics of law students' professional thinking, propose their own definition of this concept and consider its structure and structural components. The analysis of relevant literature contributed to studying the validity of the chosen topic. The article also reflects the methodology of research and its algorithm that include conducting a complex psychological and pedagogical experiment, assessing the declared parameters and fulfilling the statistical analysis of the results based on methods such as variance analysis, correlation analysis using Marsch's I coefficient, Friedman's $\mathrm{R}$ coefficient and Kruskal - Wallis H-criterion. The research base was the International Law Institute (Moscow, Russia). The experimental and control groups of subjects were formed, numbering 60 people representative in gender, etc. The results of the study demonstrate the effectiveness of combining trainings, special courses and the evolvement of formal-logical reasoning within the development of law students' professional thinking.

Keywords: legal training, professional thinking, professional formation and development.

\section{Resumen}

El artículo examina la esencia, el papel y la importancia del pensamiento profesional dentro del desarrollo profesional de los abogados, haciendo especial hincapié en los aspectos específicos del pensamiento profesional de los estudiantes de derecho en evolución. El propósito de la investigación es un estudio teórico y empírico de los aspectos específicos del desarrollo del pensamiento profesional de los estudiantes de derecho. Además, se hace hincapié en la estructura y las características del pensamiento profesional de los abogados como una cualidad de especial importancia profesional. Los autores realizan un análisis exhaustivo de los aspectos específicos del desarrollo del pensamiento profesional de los estudiantes de derecho, proponen su propia definición de este concepto y consideran su estructura y componentes estructurales. El análisis de la literatura relevante contribuyó a estudiar la validez del tema elegido. El artículo también refleja la metodología de investigación y su algoritmo que incluyen la realización de un experimento psicológico y pedagógico complejo, evaluando los parámetros declarados y cumpliendo el análisis estadístico de los resultados con base en métodos como análisis de varianza, análisis de correlación utilizando el coeficiente I de Marsch, R de Friedman. coeficiente y Kruskal-criterio H de Wallis. La base de investigación fue el Instituto de Derecho Internacional (Moscú, Rusia). Se conformaron los grupos de sujetos experimentales y de control, que sumaron 60 personas representativas en género, etc. Los resultados del estudio demuestran la efectividad de combinar capacitaciones, cursos especiales y la evolución del razonamiento lógico-formal dentro del desarrollo del pensamiento profesional de los estudiantes de derecho. .

Palabras clave: formación jurídica, pensamiento profesional, formación y desarrollo profesional.

\section{Introduction}

Nowadays one of the most pressing issues facing higher education is maximizing its effectiveness. This situation is expressed primarily in the quality of the graduates' knowledge, 
their competence and the dynamics of professional development, which is largely due to their preparedness within higher education. The above issue is of particular importance in the professions that impose special requirements on graduates, including law-related professions.

The best indicator of a lawyer's professionalism and competence is developed professional thinking. A highly qualified lawyer is able to think legally, i.e. to comprehend the facts of reality using clear juridical concepts and constructions. In particular, he/she has to assess facts in the legal format to qualify them correctly and accurately within his/her speciality.

Professional thinking is a thinking activity of a practicing lawyer or legal scholar, which is aimed at improving the quality of thinking through the skillful, competent use of the rules and means of intellectual activity. Such thinking develops the interest not only in the studied material, but also in the process of learning and comprehending this information (Volkova, Panchenko, 2018).

In fact, professional thinking is an integrative indicator of a lawyer's professionalism, which emphasizes the relevance of its development in higher educational institutions.

\section{Literature review}

The key problem in the development of a lawyer's professional thinking (LPT) is defining its structure and structural components, which follows from the diversity of legal activity and the difficulty of finding juridical universals (Gibson, 2002).

The problem of the diversity of legal activity clearly indicates several key LPT peculiarities:

- based on a specific type of activity, LPT includes both universal and special components. The universal components are the parameters required for the entire spectrum of legal activities (Mckay, Charlton, 2005), such as abstract reasoning, while the special ones are, for example, convergent and divergent thinking. This indicates that the LPT structure is basically hierarchical (Borulenkov, 2017);

- LPT requires a person to be "polypositioned", i.e. able to perceive and analyze an object using several methods in parallel (Unger, 2012). A graphic example is the analysis of a specific law both a priori and critically, which is associated with the need to follow "the letter of the law" with all its shortcomings and inconsistencies (Zykov, 2012). This thesis indicates that the LPT structure is dynamic and depends on the degree of cognitive abilities development;

- the need for "polyposition" and the necessity to switch to different types of thinking within one type of activity dictates the need for acceptable level of these mental modalities (for example, a lawmaking process requires convergent thinking to make the optimal decision and divergent thinking to predict multiple law enforcement options) (Avakyan, 2006; Kuklin, 2016). Thinking should be flexible and adaptive to changeable activity conditions, i.e. highly variable, but with stable individual elements;

- a high degree of the above-mentioned variability of thinking should manifest itself in the conditions of its very strong coherence with perception and memory, especially the operational one. The legal activity requires the free use of vast dynamic data arrays, since the laws and principles of their implementation are changeable (Burnham, 2011). Therefore, the LPT structure is characterized by the presence of stable and unstable components within the flexible system of their interconnections and a relative hierarchy between them;

- the simultaneous presence of stable and unstable elements in the structure of a lawyer's professional thinking allows us to conclude that this parameter is a population whose 
structure is apt to quick adaptation to the needs of a specific activity (Davydova, 2015). This requires not only sufficient formation of the intrastructural components, but also the structure's ability to establish relationships with various parameters (in order to include them in the population).

The considered attributive features show us that LPT is an extremely specific type of professional thinking, unique in many respects, due to the specifics of the legal activity itself. To form this type of thinking, a teacher or a psychologist needs a very special approach not only when developing this quality, but also when assessing it (Dolzhich, Dmitrichenkova, 2018).

It is possible to define LPT as a dynamic personality-based trait that allows a lawyer to comprehend the facts of reality using clear legal concepts and constructions, along with assessing facts in the legal format to qualify them correctly and accurately within his/her speciality.

\section{Research Methodology}

The experiment involved a comprehensive psychological diagnosis of professional thinking and the parameters influencing its formation. The authors propose a comprehensive programme for the development of law students' professional thinking, based on the quantitative and qualitative analysis of the assessment results obtained within traditional training and experimental formation of LPT.

The research was conducted in the International Law Institute (Moscow, Russia), involving 60 people from two relevant groups (the experimental one and the control one).

The research purpose is theoretical and empirical study of LPT developmental specifics. The attention is given to the structure and peculiarities of LPT as a special professionally important quality.

To concretize the LPT structure, we conducted the correlation analysis of the parameters selected through variance analysis with LPT expert assessment. It allowed us to define the structure of LPT, its structural components and diagnostic methods (Ponomarenko, 2017; Gorev et al., 2018; Bírová et al., 2018):

1. The cognitive component:

1.1. Peculiarities of thinking (the parameters allow a researcher both to determine the degree of development of abstract reasoning and LPT and to evaluate its general characteristics):

- ability for analysis and synthesis, productivity of thinking - "Highlighting essential features" (S. Ya. Rubinstein);

- ability for mental operations - "Complex analogies" (E.A. Korobkov);

- rigidity and flexibility of thinking - "Flexibility of thinking" (A.S. Lachins);

1.2. Perception, attention, memory - the complex Gestalt test (Manisford)

2. The personality-based component

2.1. Assessment of one's own actions - "The level of subjective control" (proposed by J. Rotter; modified by E.F. Bazhin, E.A. Golynkin and L.M. Etkind). 
2.2. Self-actualization of personality - the self-actualization test (SAT) (proposed by E. Shostrom; adapted and modified by L. Ya. Gozman and M.V. Croz).

3. The professional component

3.1. Legal consciousness and competence - "Analysis of legal consciousness components" (R.R. Muslumov)

3.2. Knowledge and understanding of law (the authors' questionnaire)

Considering the specifics of LPT structure, the change in the interconnection space will be determined using the Kruskal - Wallis criterion, since the use of other nonparametric criteria for correlation analysis is difficult due to dichotomous relationship between the parameters.

The experimental study involves the implementation of several diagnostic tasks and those presupposing the qualitative analysis of the obtained results. The control and experimental groups underwent the actions presented in Table 1.

Table (1): The algorithm of actions during the experiment

Algorithm of actions

1) concretization of LPT structural components, the ascertaining stage of the experiment

2) the formative stage of the experiment

3) the control stage of the experiment, statistical data analysis

\section{Result analysis}

The authors conducted a preliminary factor and variance analysis of the stated array of the assessed parameters. This study revealed the variance features, factor peculiarities and the specificity of the interconnection space of the studied array. The results of the factor and variance analysis are presented in Table 2 .

Within the factor analysis, we established the presence of five general populations, which are the segments of the selected array, together explaining more than $93 \%$ of the variance. This fact indicates the sufficiency of the stated parameters for solving the research problems.

Table (2): General variance populations in relation to the impact on a lawyer's efficiency General populations

\begin{tabular}{|c|c|c|c|c|}
\hline 1 & 2 & 3 & 4 & 5 \\
\hline $\begin{array}{l}\text { Abstract } \\
\text { reasoning++ }\end{array}$ & $\begin{array}{l}\text { Convergent } \\
\text { thinking }\end{array}$ & $\begin{array}{l}\text { Fluency } \\
\text { of thinking }\end{array}$ & $\begin{array}{l}\text { Communicative } \\
\text { skills }\end{array}$ & Imagination \\
\hline $\begin{array}{l}\text { Visual } \\
\text { figurative } \\
\text { thinking }\end{array}$ & $\begin{array}{l}\text { Divergent } \\
\text { thinking }\end{array}$ & $\begin{array}{l}\text { Regulation } \\
\text { of thinking }\end{array}$ & $\begin{array}{l}\text { Organizational } \\
\text { skills }\end{array}$ & Creativity \\
\hline $\begin{array}{l}\text { Visual } \\
\text { thinking in } \\
\text { action }\end{array}$ & $\begin{array}{l}\text { Creative } \\
\text { thinking }\end{array}$ & $\begin{array}{l}\text { Flexibility } \\
\text { of } \\
\text { thinking++ }\end{array}$ & $\begin{array}{l}\text { Managerial } \\
\text { skills }\end{array}$ & $\begin{array}{l}\text { Attention+ } \\
\text { perception+ } \\
\text { memory++ }\end{array}$ \\
\hline Intelligence & $\begin{array}{l}\text { Heuristic } \\
\text { thinking }\end{array}$ & $\begin{array}{l}\text { Stability } \\
\text { of thinking }\end{array}$ & $\begin{array}{l}\text { A lawyer's } \\
\text { speech culture }\end{array}$ & Reflection \\
\hline $\begin{array}{l}\text { Critical } \\
\text { thinking }\end{array}$ & & $\begin{array}{l}\text { Lability and } \\
\text { rigidity } \\
\text { of thinking }\end{array}$ & $\begin{array}{l}\text { Legal } \\
\text { competence+ }\end{array}$ & \\
\hline
\end{tabular}


Influence of

the

population on

the $\quad 0.83$

$0.83 \quad 0.6$

$0.61 \quad 0.80$

0.62

0.94

effectiveness

of a lawyer's

activity

\begin{tabular}{llllll}
\hline $\begin{array}{l}\text { Population } \\
\text { density }\end{array}$ & 0.883 & 0.515 & 0.729 & 0.564 & 0.792 \\
\hline $\begin{array}{l}\text { Total share of } \\
\text { population in } \\
\text { variance }\end{array}$ & $26.3 \%$ & $14.4 \%$ & $17.2 \%$ & $14.6 \%$ & $21.0 \%$ \\
\hline
\end{tabular}

++ - persistently included and variance-influencing parameters

The identified populations have minimal stability, their role and share in the variance in the long term is variable. This is due to rather low density of the populations, with the exception of the first and the third ones, which are the most stable and, therefore, potentially significant for variance. The impact on the efficiency of activities is variable within narrow limits, which makes it possible to focus on the study of the relevant parameters, discarding those that are unnecessary for LPT explanation.

It is advisable to consider each of the above parameters without secondary components, with the exception of situations requiring a separate illustration, since general populations have the most significant impact on activities. We should note that general populations include two high density ones (Vasbieva et al., 2018): thinking;

- abstract reasoning + critical thinking + flexibility of thinking, i.e. formal logical

- attention + memory + thinking.

These populations have significant density, more than 0.755 , which indicates the need to consider them in this particular form within the study.

The factor structure of the parameters shows that they correlate with LPT peculiarities that were discussed above, which is due to the variability of their stability, along with the presence of both dense and non-dense formations. At the same time, the populations 1 and 5 are universal elements of professional thinking, while the population 2 is a special element. "Polyposition" is expressed in the fact that various population components are included in the activity in parallel, and not sequentially (Sharonova, Trubnikova, Sokolova, 2018).

Although we did not reveal a clear hierarchy between the populations, it was possible to establish that the populations 1 and 5 are crucial for the variance, while the population 1 is denser and, therefore, significant. Such structure indicates the instability of the relationship between all the parameters, except those included in the general population, which makes it necessary to use such statistical criteria as the Marsch criterion and the Kruskal - Wallis criterion (Blinova, Dugina, Zabolotskikh, 2018).

It can be concluded that the peculiarities of thinking play a more important role in the LPT structure than the development level of certain thinking types and mental operations (based on the fact that the most important LPT population is reduced to the development level of formal logical thinking). The above is due to a wide range of activities and the need to switch from one type of activity to another. The levels of LPT formation, their peculiarities and specificity of dynamics will be presented within the interpretation of the results obtained at the ascertaining and control stages. 
The factor structure indicates a normative distribution. Therefore, it is possible to identify the optimal LPT state, which can be used as a standard in the context of this study. Mathematically, this state represents the optimal structure, strength, ramification and the nature of the relationship between the parameters, which has the most favourable effect on a lawyer's activity.

Let us note that the influence of professional thinking (populations 1, 3, 5) on activities can be dichotomous or negative, which makes this division possible.

The ascertaining stage of the experiment involved the complex LPT assessment in the experimental and control groups with the further interpretation of the obtained information.

The comprehensive LPT assessment allows us to conclude that the cognitive, personality-based and professional LPT components are developed at an average level.

Let us pay attention to the correlation analysis of the cognitive components parameters using Marsch's and Friedman's criterion, which enables the authors to make the conclusions that are important for the research. The data are presented in Table 3.

Table (3): Multiple and unbalanced correlation analysis of LPT expert assessment with the structural elements of the cognitive component

\begin{tabular}{|c|c|c|c|c|c|c|c|}
\hline & \multicolumn{6}{|c|}{ LPT cognitive component } \\
\hline & & $\begin{array}{ll}\text { Formal and } \\
\text { logical } \\
\text { reasoning }\end{array}$ & $\begin{array}{l}\text { Memory } \\
\text { thinking } \\
\text { attention }\end{array}$ & $\begin{array}{l}+ \\
+\end{array}$ & $\begin{array}{l}\text { Flexibility } \\
\text { of thinking }\end{array}$ & $R$ & \\
\hline & & $\begin{array}{ll}\text { Exp. } & \text { Control } \\
\text { group } & \text { group }\end{array}$ & $\begin{array}{l}\text { Exp. } \\
\text { group }\end{array}$ & $\begin{array}{l}\text { Control } \\
\text { group }\end{array}$ & $\begin{array}{l}\text { Control } \\
\text { group }\end{array}$ & $\begin{array}{l}\text { Exp. } \\
\text { group }\end{array}$ & $\begin{array}{l}\text { Control } \\
\text { group }\end{array}$ \\
\hline LPT & expert & $0.61^{*}$ & $0.86^{* *}$ & $0.85^{* *}$ & $0.64^{*}$ & $0.58^{* * * *}$ & $0.59 * * *$ \\
\hline
\end{tabular}

assessment $\mathrm{p} \leq 0,05-*, \mathrm{p} \leq 0,01-* * ; \mathrm{p} \leq 0,001-* * *$.

The results presented in Table 3 allow us to conclude that LPT expert assessment is a very accurate criterion for the connectivity of the parameters and the optimality of the factor structure. According to the results of the variance, the cognitive component is the key LPT constituent, since it includes two general populations.

The results of unbalanced correlation analysis demonstrate the strongest connection with the least developed parameter, defining the so-called development boundary of the whole population until its transformation dynamics enables it to move to another range of values. $\mathrm{R}$ is proportional to the optimality of the factor structure, which is low in both groups of subjects. In fact, this means that the cognitive component is the crucial one within LPT development.

Therefore, it is clear that LPT formation directly depends on the development level of the cognitive component, especially the subjects' memory, thinking and attention of the subjects. These parameters also affect LPT factor structure. In fact, its optimization is determined by the degree of their formation, and not by the strengthening of the relationship between the parameters. Thus, the improvement of students' memory, thinking and attention in conjunction with formal-logical reasoning is a key condition for LPT development.

The ascertaining stage of the research shows us that LPT development should be implemented in a training form, based on the formation of the subjects' formal-logical reasoning, memory, thinking and attention. It is important for the development of the professional component, along with knowledge in the legal field.

The formative stage includes two components - training seminars on developing the cognitive and personality-based LPT components and the inclusion of a special course on the legal consciousness development in the educational programme. 
At the control stage we used the same diagnostic tools as at the ascertaining one. The focus was on determining the effectiveness of the implemented technology for the students' LPT development, using the methods of mathematical and statistical data processing.

The comparative analysis of the cognitive component at the ascertaining and final stages highlighted the significant changes in both groups of subjects.

In the control group, such parameters as the stability of thinking and the attention components demonstrate positive dynamics, passing from the "average" range of values to the "high" one. This trend is due to purposeful development of attention, which is facilitated by studying legal norms and connections between them. Stability of thinking develops when a subject comprehends the structure of codes, in proportion to the time that the participants spend on this process. Considering the memory growth dynamics in the control group, we can state it does not change more quickly or more slowly, which is associated with the features of this parameter's development. Memory is a quality that effectively develops in adolescents due to targeted measures, through the development of specific methods of data processing.

The analysis of the assessment results obtained in the experimental group demonstrates much more considerable and gradual dynamics of changes. Within the attention components it exceeded $25 \%$, and such parameters as velocity and selectivity reached the "very high" value. The accuracy came close to the borders of this range with very high dynamics growth. The increase in attention components is one of the reasons why the dynamics of LPT changes exceeds the limits of the identified interconnection space peculiarities. This quality significantly intensifies sensory and perceptual acts, reducing the intervals between them. However, it requires the participation of third-party psychological mechanisms (such as noise immunity) that function as a "firewall".

Adherence to this condition increases the volume of perceived environmental objects per unit of time, while maintaining the same level of perception errors. The control group does not exceed the features of symmetry and cycles of indicators because the adequate realization of the benefits of more rapid attention switching also requires a commensurate level of processing perceptual data, which depends on such parameter as thinking and, partly, flexibility of thinking.

We can observe that the stability of thinking is the only indicator that shows stable increase, while self-regulation of thinking demonstrates stagnation in the growth dynamics, in contrast with the reverse process in the experimental group. The synchronous growth of attention components with the components of thinking, provided due to training sessions at the formative stage, made it possible to realize the described tendency within the experimental group's practical activity.

It is also worth noting the high and coherent dynamics of memory growth in the subjects of the experimental group who moved to the "high" range of values, showing an increase of more than $20 \%$. The development of the response speed indicator in the abovementioned group, in contrast with the dynamics stagnation in the control group, is also important. The indicator increased by more than 50\% in the experimental group (from 11.6 at the $1^{\text {st }}$ stage to 17.8 at the $3^{\text {rd }}$ stage), in contrast with the growth by less than $10 \%$ in the control group (from 11.3 at the $1^{\text {st }}$ stage to 11.8 at the $3^{\text {rd }}$ stage). This tendency is associated with the development of attention within the experimental group.

Summing up, we can indicate the effectiveness of developing the cognitive component elements at the formative stage, which is illustrated by the analysis of the relative parameters diagnostics. To identify changes in the interconnection space, we conducted multiple and unbalanced correlation analysis of LPT expert assessment in the experimental group with the components of LPT cognitive component structure. The data are presented in Table 4. 
The repeated correlation analysis of the cognitive component allows us to conclude that LPT factor structure is entirely determined by its cognitive component, and the general populations do not change depending on the degree of parameters' formation. This confirms the thesis that the factor structure depends on the formation of the parameters included in the general population and is relatively autonomous from the relationship between them. In fact, we can conclude that the state and dynamics of LPT are $80 \%$ determined by the cognitive component, while the personality-based and professional components are important only within the evolvement of the parameters included in the LPT cognitive component structure. In the course of the improvement of formal-logical reasoning, attention, memory and thinking, these elements affect the partiality of the mentioned parameters, the variety of their implementation in professional activities, but lose their direct influence on LPT.

Table (4): Multiple and unbalanced correlation analysis of LPT with the structural elements of the LPT cognitive component

\begin{tabular}{|c|c|c|c|c|c|c|c|c|}
\hline & \multicolumn{8}{|c|}{ LPT cognitive component } \\
\hline & \multicolumn{2}{|c|}{$\begin{array}{l}\text { Formal and } \\
\text { logical } \\
\text { reasoning }\end{array}$} & $\begin{array}{l}\text { Memory } \\
\text { thinking } \\
\text { attention }\end{array}$ & $\begin{array}{l}+ \\
+\end{array}$ & \multicolumn{2}{|c|}{$\begin{array}{l}\text { Flexibility } \\
\text { of thinking }\end{array}$} & $R$ & \\
\hline & $\begin{array}{l}\text { Exp. } \\
\text { group }\end{array}$ & $\begin{array}{l}\text { Control } \\
\text { group }\end{array}$ & $\begin{array}{l}\text { Exp. } \\
\text { group }\end{array}$ & $\begin{array}{l}\text { Control } \\
\text { group }\end{array}$ & $\begin{array}{l}\text { Exp. } \\
\text { group }\end{array}$ & $\begin{array}{l}\text { Control } \\
\text { group }\end{array}$ & $\begin{array}{l}\text { Exp. } \\
\text { group }\end{array}$ & $\begin{array}{l}\text { Control } \\
\text { group }\end{array}$ \\
\hline $\begin{array}{l}\text { LPT expert } \\
\text { assessment }\end{array}$ & $0.81 * *$ & $0.63^{*}$ & $0.92 * * *$ & $0.85^{* *}$ & $0.78 * *$ & $0.64 *$ & $0.80 * * *$ & $0.58 * * *$ \\
\hline
\end{tabular}

Further, in order to test LPT effectiveness among the students, we used the method of mathematical and statistical statistics - the Wilcoxon signed-rank test. This criterion allows determining the reliability of the shift in the studied parameters within the control and experimental groups. The analysis of the data obtained in both groups after using the Wilcoxon signed-rank test enables us to assert that there are statistically significant changes in the experimental group (that occurred since the initial examination of students).

Therefore, the considerable difference in these groups' results can be explained by the effective impact of the formative experiment, during which the participants showed substantial increase in the indicators of the key components and the legal awareness level in general, while there were no significant changes in the control group.

\section{Conclusion}

Based on the results of the study, we made the following conclusions:

1. In the structured parameter, which includes the cognitive, personality-based and professional components, the cognitive one is the most important. It includes two general populations: 1) formal logical reasoning, which manifests itself in mastering formal logic, abstract concepts and connections between objects; 2) the population including memory, thinking and attention.

2. The development of the cognitive component determines the degree of LPT development, while the personality-based and professional components have an indirect effect on this process, ensuring the partial involvement of professional thinking in various aspects of professional activity and affecting the improvement dynamics.

3. LPT development is achieved through the inclusion of professionally oriented situations and trainings in the educational process of the university. 


\section{References}

Avakyan, T.V. (2006). Yuridicheskoye myshleniye v pravoprimenitel'nom protsesse [Legal thinking in law enforcement process]. Rostov-on-Don: Rostov Law Institute of the Russian Ministry of Internal Affairs.

Bírová, J., Kružlík, P., Kalimullin, A., Sokolova, N., Haroun, Z., Králik, R., Vasbieva, D. (2018). Mathematical and Statistical Bibliometric Indicators for Scholars in the Field of Romance Languages and Linguistics. EURASIA: Journal of Mathematics, Science and Technology Education, 14(12): 1-15.

Blinova, S., Dugina, T., Zabolotskikh, A. (2018). Teaching mixed nationality groups (on the example of students from the Northern Caucasus region). INTED2018: Proceedings of the 12th International Technology, Education and Development Conference (pp. 7977-7982). Valencia, Spain.

Borulenkov, Yu. P. (2017). Pravovoye myshleniye kak intellektual'naya sostavlyayushchaya yuridicheskogo poznaniya [Legal thinking as an intellectual component of law knowledge]. Izvestiya VUZov. Pravovedeniye [Journal of Universities. Jurisprudence], 2(331).

Burnham, W. (2011). Introduction to the Law and Legal System of the United States. St. Paul: Thomson/West.

Davydova, M.L. (2015). Professional'noye myshleniye yuristov v sravnitel'no-pravovom rakurse. Vestnik Universiteta imeni O. Ye. Kutafina [Bulletin of Kutafin Moscow State Law University], 5: 66-72.

Dolzhich, E., Dmitrichenkova, S. (2018). Computer science terminology (a case study of the Spanish language). INTED2018: Proceedings of the 12th International Technology, Education and Development Conference (pp. 2556-2559). Valencia, Spain.

Gibson, R. (2002). Intercultural Business Communication. Oxford: Oxford University Press.

Gorev, P., Telegina, N., Karavanova, L., Feshina, S. (2018). Puzzles as a didactic tool for development of mathematical abilities of junior schoolchildren in basic and additional mathematical education. EURASIA: Journal of Mathematics, Science and Technology Education, 14(10): 178-185.

Kuklin, S.V. (2016). K voprosu o strukture yuridicheskogo myshleniya [On the structure of legal thinking]. Vestnik YUUrGU. Seriya: Pravo [Bulletin of South Ural State University. Section: Law], 16(3): 22-26.

Mckay, W.R., Charlton, H.E. (2005). Legal English: how to understand and master the language of law. Harlow: Pearson-Longman.

Ponomarenko, E.V. (2017). Pravovoye osvoyeniye v sisteme kategoriy teorii prava [Legal development in the system of categories of the theory of law]. Ekaterinburg: Ural State Law University.

Sharonova, S., Trubnikova, N., Sokolova, N. (2018). Interpreting religious symbols as basic component of social value formation. European Journal of Science and Theology, 14(3): 117-129.

Unger, R.M. (2012). Law in Modern Society. New York: The Free Press.

Vasbieva, D.G., Sokolova, N.L., Masalimova, A.R., Shinkaruk, V.M., Kiva-Khamzina, Y.L. (2018). Exploring the EFL teacher's role in a smart learning environment - a review study. XLinguae, 11(2): 265-274.

Volkova, Y., Panchenko, N. (2018). Discourse variation of the concepts of destructive emotions. Vestnik Rossiiskogo Universiteta Druzhby Narodov. Russian journal of linguistics, 22(1): 175-194.

Zykov, D.V. (2012). Nekotoryye voprosy teorii yuridicheskogo myshleniya [Some issues of the theory of legal thinking]. Legal Concept, 2(17): 274-280.. 